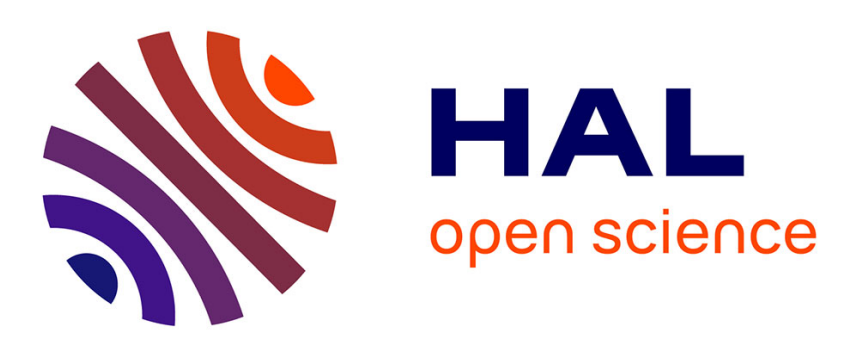

\title{
Age-hardening characteristics of $\delta$-alumina fibre reinforced aluminium-silicon LM-13 alloy metal matrix composites
}

\author{
H. Akbulut, M. Durman, F. Yilmaz
}

\section{> To cite this version:}

H. Akbulut, M. Durman, F. Yilmaz. Age-hardening characteristics of $\delta$-alumina fibre reinforced aluminium-silicon LM-13 alloy metal matrix composites. Journal de Physique IV Proceedings, 1993, 03 (C7), pp.C7-1757-C7-1760. 10.1051/jp4:19937278 • jpa-00251919

\section{HAL Id: jpa-00251919 https://hal.science/jpa-00251919}

Submitted on 1 Jan 1993

HAL is a multi-disciplinary open access archive for the deposit and dissemination of scientific research documents, whether they are published or not. The documents may come from teaching and research institutions in France or abroad, or from public or private research centers.
L'archive ouverte pluridisciplinaire $\mathbf{H A L}$, est destinée au dépôt et à la diffusion de documents scientifiques de niveau recherche, publiés ou non, émanant des établissements d'enseignement et de recherche français ou étrangers, des laboratoires publics ou privés. 


\title{
Age-hardening characteristics of $\delta$-alumina fibre reinforced aluminium-silicon LM-13 alloy metal matrix composites
}

\author{
H. AKBULUT, M. DURMAN and F. YILMAZ \\ The University of Sakarya, 54188 Adapazan, Turkey
}

\begin{abstract}
Metal Matrix Composites (MMCs) with an aluminium-siuicon based LM-13 alloy and short-staple Saffil ( $\hat{S}$-alumina) fibres with volume fractions of $0.10,0.15,0.20,0.25$ and 0.30 have been produced using a pressure liquid infiltration process. The standard T6 heat treatment procedure was applied to both the unreinforced matrix alloy and the composites, and the effect of the fibres on the age-hardening characteristics of the composites has been investigated by means of hardness measurements.
\end{abstract}

\section{INTRODUCTION}

Reinforcement of aluminium alloys with short staple 8-alumina fibres are of commercial importance in recent years because of the enhanced mechanical properties of the resuiting composites, particularly at elevated temperatures. The evolntion of such composites in the marketplace has been rapid, and antomobile components such as diesel pistons, connecting rods, piston pins etc, are now being routinely fabricated to meet more stringent property requirements [1,2]. In these applications, stort alumina fibres are fabricated into a preform, usually in random-planar orientation, and than infiltrated with molten metal under pressure. Most work in this field has concentrated on the fabrication routes and the characterization of the mechanical and physical properties of the resulting composites depending on the fibre volume fraction $[3,4,5]$, but little consideration is given to the effect of the fibres on the age-hardening response of the matrix material upon heat-treatment. This is particularly important since most of the matrices used in Metal Matrix Composites (MMCs) are usually age-hardenable alloys. This work was undertaken to deternine the age-hardening characteristics of ICI's "Saffil" alumina fibre reinforoed traditional alumnium piston alloy LM-13 composites containing various volume fractions of Saffil fibres.

\section{EXPERIMENTAL WORK}

The matrix LM-13 alloy used in the experiments was of commercial grade, and the composition was determined as: $\mathrm{Al}-12 \% \mathrm{Si}, 1.16 \% \mathrm{Cu}, 1.21 \% \mathrm{Mg}, 0.90 \% \mathrm{Ni}, 0.17 \% \mathrm{Zn}, 0.12 \% \mathrm{Mn}, 0.48 \% \mathrm{Fe}, 0.006 \% \mathrm{~Pb}, 0.05 \% \mathrm{Ti}, 0.001 \% \mathrm{Cr}$, $0.001 \% \mathrm{Sn}$. The composites have been produced by a pressure liquid infiltration process using Saffil alumina fibre preforms containing $10 \%, 15 \%, 20 \%, 25 \%$ and $30 \%$ by volume of Saffil. These preforms were $100 \mathrm{~mm}$ in diameter and $10 \mathrm{~mm}$ in thickness accommodating the fibres, $3 \mu \mathrm{m}$ in diameter with an average length of $500 \mu \mathrm{m}$, predominately in random planar orientation. The infiltration of the preforms were carried out as follows: The preforms were placed in a steel die cavity which was connected to the molten alloy in a pressure vessel by a tube, and 
heated to $450^{\circ} \mathrm{C}$ while both the die cavity and the pressure vessel were being evacuated. Once the evacuation was complete and the required die and melt temperature $\left(800-850^{\circ} \mathrm{C}\right.$ ) was obtained, the gas pressure of $3 \mathrm{MPa}$ was applied to the to the pressure vessel until the preforms were fully infiltrated.

Brinell Hardness measurements were carried out on ground and polished samples, using $187.5 \mathrm{kgf}$ load and a ball 2.5 $\mathrm{mm}$ in diameter. The measurements were carried out on both planar and transverse sections, and at least ten impressions were made to determine the mean value of the hardness on each section.

The standard T6 heat treatment procedure was applied to bot unreinforced alloy and the composite by holding the samples at $515^{\circ} \mathrm{C}$ for 8 hours followed by quenching and aging at $171^{\circ} \mathrm{C}$ for 15 hours.

\section{RESULTS}

The hardness measurements obtained from the planar and transverse section of the unreinforced alloy and the composites before and after heat treatment are listed in Table 1, and graphically shown in Figure 1. It is noted from these that in both as-cast and heat-treated condition, the hardness on the transverse sections of the composites was slightly higher by about 2-9 HBN than that on the planar sections, and the hardness of the composites increased with increasing volume fraction of the Safil fibres. The increase was particularly marked between the fibre volume fractions of $10 \%$ and $15 \%$. The increase in the hardness of the unreinforced alloy and the composites upon heattreatment is graphically shown in Figure 2. It is clear from this figure that the increase in the hardness of the unreinforced matrix alloy upon heat-treatment was about $40 \mathrm{HBN}$. This increase remain essentially unchanged for the composite with Saffil volume of $10 \%$, and then increased to reach a peak at that with $15 \%$ Saffil. The increase in the hardness attained at that point was about $45 \mathrm{HBN}$. But the hardening response of the composites containing higher volume fractions of Saffil fibres degraded sharply, and the increase, upon heat-treatment, obtained in the hardness of the $30 \%$ fibre composite was only about $23 \mathrm{HBN}$. The results indicated that the fall in the hardening response of the composites with increasing volume fraction of the fibers was much faster than the that expected due to the decreased matrix volume fractions, suggesting that the fibres had an important effect on the age-hardening response of the matrix alloy.

Light optical metallograpy carried out on the matrix alloy and the transverse sections on the composites is shown in Figure 3. It was clear from the micrographs of the lower fibre composites that there was clusters of fibres segregated in inter-dendritic regions. Increased fibre volume had produced a uniform distribution of fibres and a modified structure.

\section{Acknowledgements}

The authors wish to gratefully acknowledge the Scientific and Technical Research Council of Turkey (TUBITAK) for funding the work.

\section{REFERENCES}

[1] DONOMOTO T., FUNATANI K., MIURA N., MYYAKE N., SAE Paper No: 830252 (1983).

[2] DINWOODIE J, SAE Paper No: 870437 (1987).

[3] DINwOODIE J., MOORE E., LANGMAN C.A.J., SYMES W.R., Proc. 5th Int. Conf. on Composite Materials, San Diego, California (1985) 671.

[4] COOK C.R., YUN D.I., HUNT W.H., Proc. Int. Symposium on Advance in Cast Reinforced Metal Composites, Chicago, Ilinois (1988) 195.

[5] BAXTER W.J, Metall. Trans.A 23A (1992) 3045. 
Table 1. Brinell Hardness of the as-cast and the heat-treated unreinforced matrix alloy and composites

\begin{tabular}{lccccc}
\hline \multirow{2}{*}{ Materials } & \multicolumn{2}{c}{ As-Cast } & & \multicolumn{2}{c}{ Heat-Treated } \\
\cline { 2 - 5 } & Transverse & Planar & & Transverse & Planar \\
\hline LM-13 (Unreinforced) & 90 & 90 & 130 & 130 \\
LM-13+10\% Saffil & 95 & 93 & 136 & 133 \\
LM-13+15\% Saffil & 119 & 114 & 165 & 159 \\
LM-13+20\% Saffil & 136 & 131 & 170 & 162 \\
LM-13+25\% Saffil & 143 & 134 & 175 & 169 \\
LM-13+30\% Saffil & 156 & 150 & 178 & 174 \\
\hline
\end{tabular}

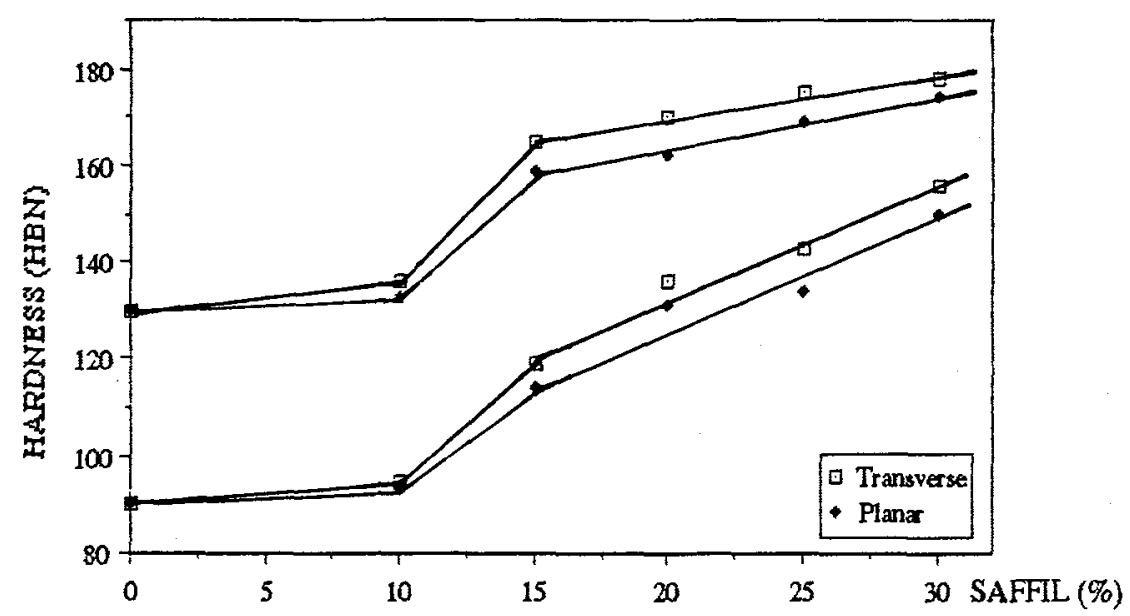

Figure 1. Variation of Brinell hardness of the as-cast and the heat-treated composites with volume percent Saffil fibre

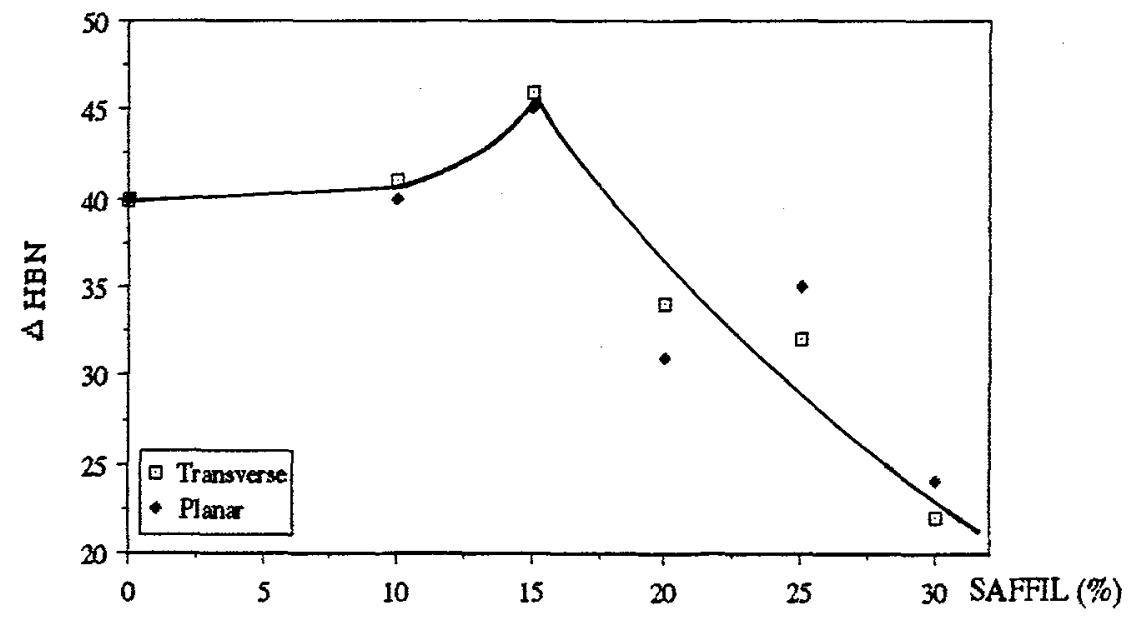

Figure 2. Variation of the increase in hardness upon heat-treatment with volume fraction of Saffil fibre. 


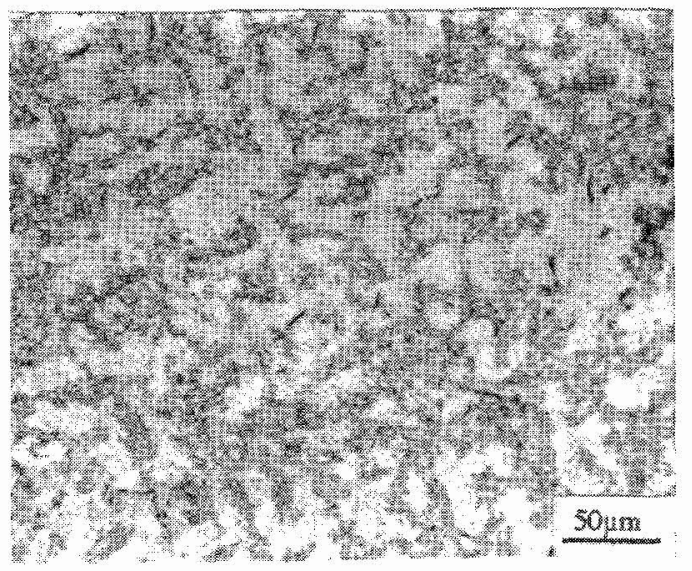

(a)

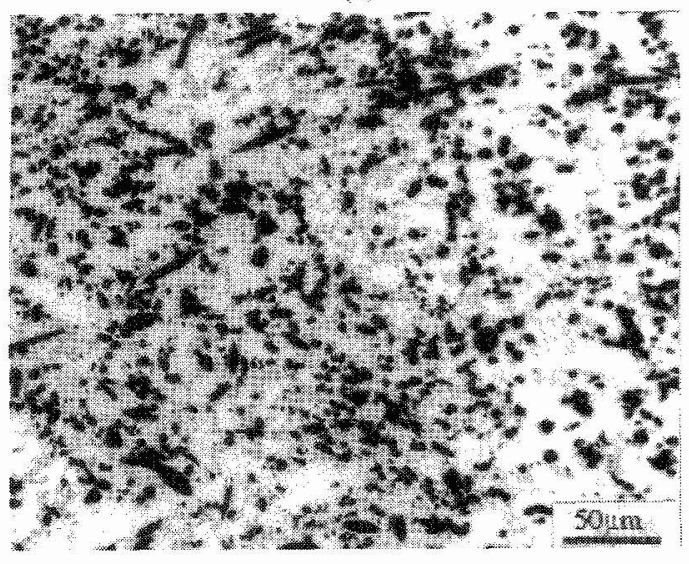

(c)

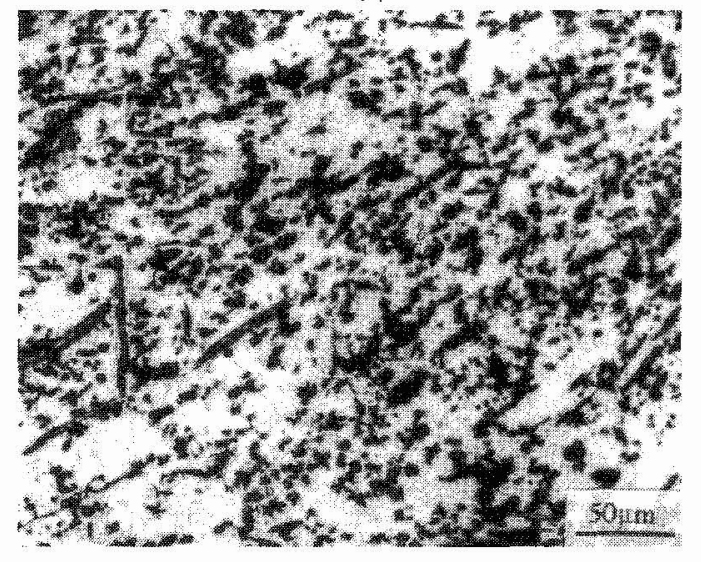

(e)

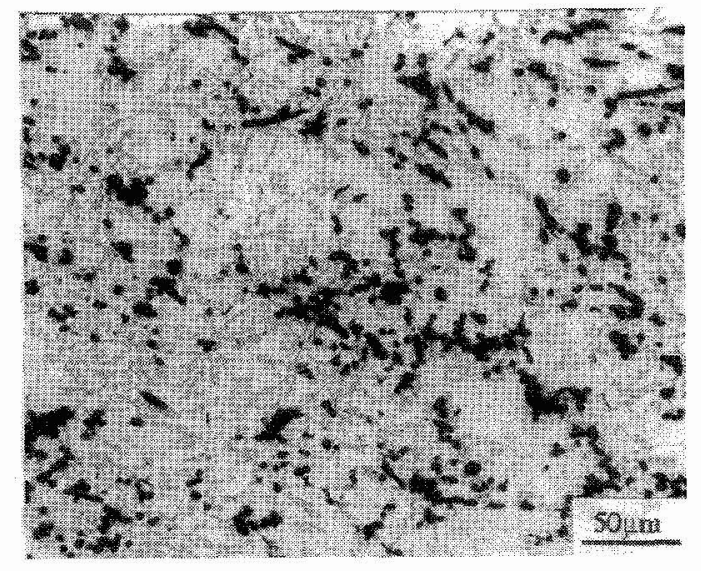

(b)

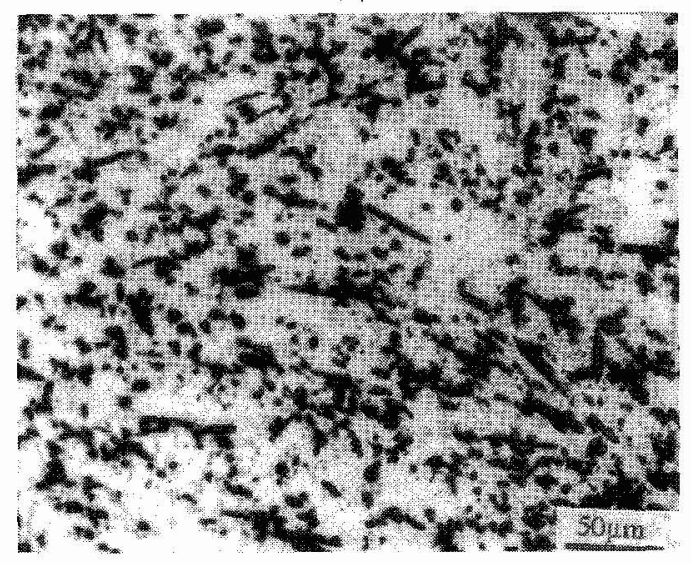

(d)

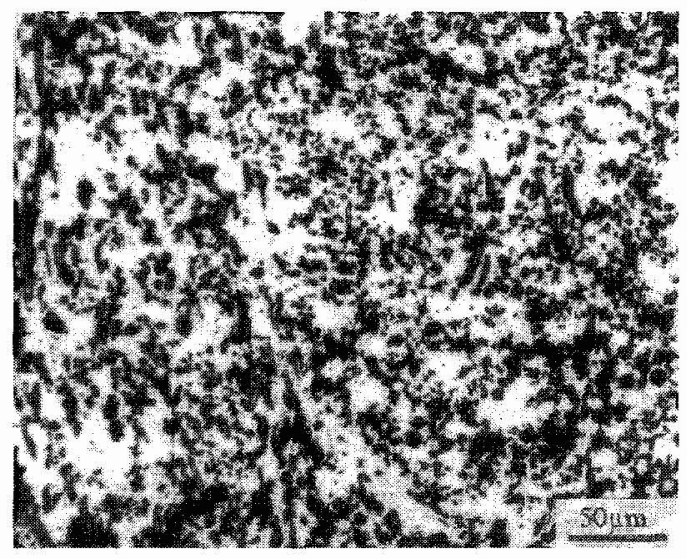

(f)

Figure 3. Optical micrographs of (a) Unreinforoed LM-13 matrix alloy, and radial distribution of fibres in transverse section of the composites with (b) $10 \%$, (c) $15 \%$, (d) $20 \%$, (e) $25 \%$ and (f) $30 \%$ by volume of Saffil fibre. 